\title{
ON SOME NAMES OF BRAGA AND MOONSHINE IN NORTHERN RUSSIAN DIALECTS ${ }^{1}$
}

\author{
Ksenia V. Osipova \\ Ural Federal University named after the first President of Russia B.N. Yeltsin, Yekaterinburg, Russia
}

\begin{abstract}
The article represents the description of the group of homemade alcoholic beverages names, which exist in the dialects of Arkhangelsk, Vologda and Kostroma regions. The study is based on lexical materials of the Toponymic Expedition of the Ural University, as well as dialect dictionaries, which include the lexemes used on the territory of the Russian North. The peculiarities of vocabulary formation and the influence of social, demographic and economic factors on its formation are revealed. Semantic-motivational and etymological analysis of dialectal lexemes showed that this group of vocabulary, along with the original Northern Russian units, includes borrowings from Volga dialects, semi-professional languages and the words originating from foreign sources (polonism, turkism). The author identified sustained motivational models presented in the considered nominations: the semantics of "homemade intoxicating drink" emerges from the alteration of meanings "low-quality liquid"; "disorder, bustle", "prank, hooligan"; "talk, chatter". The peculiarities of this lexical group were influenced by governmental bans on home brewing: there are a large number of euphemisms and variability of the lexical group. Compared with beer, home brew and moonshine in the Russian North were considered second-rate drinks and were associated with alcohol addiction, while drinking beer rarely caused social condemnation.
\end{abstract}

Key words: Russian language, North Russian dialects, alcoholic drinks, ethnolinguistics, vocabulary, etymology, traditional culture.

Citation. Osipova K.V. On Some Names of Braga and Moonshine in Northern Russian Dialects. Vestnik Volgogradskogo gosudarstvennogo universiteta. Seriya 2. Yazykoznanie [Science Journal of Volgograd State University. Linguistics], 2020, vol. 19, no. 4, pp. 29-41. (in Russian). DOI: https://doi.org/10.15688/jvolsu2.2020.4.3

\section{О НЕКОТОРЫХ НАЗВАНИЯХ БРАГИ И САМОГОНА В СЕВЕРНОРУ ССКИХ ГОВОРАХ ${ }^{1}$}

\author{
Ксения Викторовна Осипова \\ Уральский федеральный университет им. первого Президента России Б.Н. Ельцина, \\ г. Екатеринбург, Россия
}

\footnotetext{
Аннотация. В статье охарактеризована группа номинаций крепких спиртных напитков домашнего приготовления в говорах Архангельской, Вологодской и Костромской областей. Исследование выполнено на лексическом материале картотеки Топонимической экспедиции Уральского университета, а также диалектных словарей, в которых зафиксированы лексемы, бытующие на территории Русского Севера. В результате семантико-мотивационного и этимологического анализа диалектных единиц установлено, что эту группу наряду с исконными севернорусскими единицами формируют заимствования из поволжских говоров, условно-профессиональных языков, а также слова, восходящие к иноязычным источникам (полонизм, тюркизм). Выявлены устойчивые мотивационные модели, реализованные в рассмотренных номинациях: значение 'домашний хмельной напиток’ возникает на основе переосмысления значений 'некачественная жидкость', ‘беспорядок, суматоха', ‘пройдоха, хулиган', 'разговор, болтовня'. () Описаны особенности названий домашних крепких спиртных напитков, обусловленные государствен-
} 
ными запретами на домашнее самогоноварение: большое количество эвфемизмов, многочисленность и вариативность номинаций. На основе примеров использования слов, называющих крепкие спиртные напитки, показано, что в локальной культуре Русского Севера брага и самогон, в отличие от пива, считались напитками второго сорта, их употребление ассоциировалось с пьянством и вызывало социальное осуждение.

Ключевые слова: русский язык, севернорусские говоры, спиртные напитки, этнолингвистика, лексика, этимология, традиционная культура.

Цитирование. Осипова К. В. О некоторых названиях браги и самогона в севернорусских говорах // Вестник Волгоградского государственного университета. Серия 2, Языкознание. - 2020. - Т. 19, № 4. - С. 29-41. DOI: https://doi.org/10.15688/jvolsu2.2020.4.3

\section{Введение}

В 2008 г. было опубликовано масштабное исследование Г.Ю. Багриновского «Энциклопедический словарь спиртных напитков» (Багриновский, 2008), в котором собрано, систематизировано и снабжено историко-лингвистическими комментариями более 3500 наименований. Эта необычайно многочисленная группа объединила в себе лексические единицы, принадлежащие разным подъязыкам и слоям культуры: говорам и народной культуpe, арго и традиционно-профессиональной культуре, просторечию и «третьей» культуре, литературному языку и (согласно терминологии Н.И. Толстого) элитарной культуре [Толстой, 2013 , с. 8]. Изучение указанной лексической группы особенно продуктивно в историко-филологическом аспекте с точки зрения происхождения лексических единиц и языковых влияний - не только внешних (иноязычных) контактов, но и внутренних, например проникновения арготической лексики в русские говоры, просторечия в литературный язык, книжных лексем в разговорную речь. При этом естественным образом возникает необходимость проследить судьбу «слов и вещей» («Wörter und Sachen»): сохранение или утрату традиционных способов приготовления напитков и их названий, а также появление новых наименований в связи с употреблением новых хмельных напитков и их переходом из одной субкультуры или субъязыка в другой культурно-языковой слой.

В статье данная группа лексики рассматривается в региональном аспекте с целью охарактеризовать опосредованное отражение в семантике языковых единиц локальной севернорусской традиции приготовления и потребления хмельных напитков.

\section{Материал и методы исследования}

Объектом исследования стали названия браги и самогона, отмеченные на территории Архангельской, Вологодской и Костромской областей, где на протяжении многих лет лексический материал собирали участники Топонимической экспедиции Уральского университета. Основным источником севернорусских данных послужили картотеки, хранящиеся на кафедре русского языка, общего языкознания и речевой коммуникации Уральского университета (КСГРС; ЛКТЭ), а также региональные лексикографические издания (АОС; СВГ; СГРС; и др.).

Методика семантико-мотивационной реконструкции, разработанная учеными Уральской школы ономастики, этнолингвистики и этимологии (см., например: [Березович, 2014; Леонтьева, 2015]), позволяет не только охарактеризовать происхождение слов, их семантические связи и этапы формирования значений, но и реконструировать пласт связанных с ними народных представлений.

Для исследователя локальной традиции группа наименований хмельных напитков интересна с точки зрения путей ее формирования, поскольку в нее входят как исконные единицы, сохраняющие архаические черты, так и названия, пришедшие извне - из других разновидностей одного языка (литературного языка, просторечия или жаргона) или других языков. Такие заимствования - это результат влияния на язык многих социально-демографических и экономических факторов: межэтнические контакты, контакты с жителями более южных территорий, особенности производства или поставок нелегального алкоголя, государственные запреты на продажу алкоголя и др. 
Данная статья завершает серию наших публикаций, посвященных этнолингвистическому анализу севернорусской лексики пивоварения и наименований крепких алкогольных напитков [Осипова, 2017; 2018].

\section{Результаты и обсуждение}

На Русском Севере брага считалась напитком более низкого качества, чем пиво. Иногда брагой называли пиво, сделанное дома в корчагах (корчажная бражка) в отличие от настоящего пива, которое варили коллективно в больших котлах (сольвыч. котловое пиво) (Тенишев, с. 498-499). Как и пиво, брага готовилась путем варки, о чем напоминают многие названия с корнем -вар-, ср.: арх. варя (СРНГ, вып. 4, с. 63), перева́ра: «Бьет челом и встречает княгиня молодая. Хлебом, солью, сладким медом и пьяной переварой» (свадебная песня) (СРНГ, вып. 26, с. 42). В Архангельской области под брагой подразумевали напиток, вторично приготовленный на основе пивной гущи, ср.: вин. друга́н 'брага': «Из остатков пива друган делали» (КСГРС).

Варили брагу и самогон часто, поскольку это выходило проще и дешевле, чем приготовление пива: использовалось все, что оказывалось под рукой, - «отходы» от пива, сахар, зерно, хлеб, картошка, ягоды и пр. Она была вторичным напитком и по вкусовым качествам всегда проигрывала пиву и даже квасу, ср.: арх. лен. чи́квас 'брага' (КСГРС), образованное с помощью экспрессивной приставки чи-, а также присловья: «Пей пиво, не брагу и люби девку, не бабу; Была бражка, да вышли барашки, теперь есть квас, да не про вас» (Ефименко, с. 247, 243). Если пиво пили и мужчины, и женщины, то брага и самогон считались атрибутом мужской компании. Значительно у́же был спектр их знаковых функций: брага и самогон, обладая скудной обрядовой символикой, ассоциировались преимущественно с пьянством (ср.: костром. галич. врезаться в самого́ночку 'начать пить, пьянствовать' (СРНГ, вып. 36, с. 83)), тогда как питье пива редко вызывало социальное осуждение. Негативное отношение к употреблению алкоголя и восприятие спиртного как греха находим, например, в костром. пав. грех: носить (давать) греха 'алкоголь; носить (давать) кому-л. спиртное': «Нельзя носить греха на кладбишше; Не давали греха детям и родителям; Будешь носить греха - в ад попадешь» (ЛКТЭ), волог. сямж. сатана́ 'самогон': «Сатану, наверно, варят» (СВГ, т. 9, с. 94) ${ }^{2}$. Последнее выражение сопоставимо с литературным сатани́нская кровь, сатани́нский напиток, кровь сатаны 'водка' (Багриновский, 2008, с. 502), отмеченными в книжном языке XIX в. (например, у А.П. Чехова, Л. Андрееева, ШоломАлейхема). В противоположность вину, которое в библейской традиции может отождествляться с кровью Христовой, водка и другие крепкие напитки считались порождением темных сил.

Одним из самых распространенных названий хмельного напитка на Русском Севере было слово брага ${ }^{3}$ и его производные, которые свидетельствуют о шутливо-ироничном отношении к браге и ее употреблению: арх., волог., костром. бра́жка (АОС, вып. 2, с. 99), волог. баб. брагу́лька, бра́нька, кад. брыгу́лька, костром. бращёнка (КСГРС; ЛКТЭ). Брага стала символом пьянства и безделья, ср.: бра́жничать волог. 'пить хмельные напитки, пьянствовать' (СВГ, т. 1, c. 43), арх. плес. 'коротать время', онеж. 'проводить время за едой и питьем' (АОС, вып. 2, с. 99): «У чашников да у бражников много в году праздников (арх.)» (Ефименко, c. 249), а также символом коллективного невоздержанного поведения, ср.: арх. бра́жка 'дурная компания, ватага': «Народ худой сообран, бражка. Их было брашки три тыщи большие» (АОС, вып. 2, с. 99).

Мотив веселья и игры, ассоциирующийся со спиртными напитками, находит отражение в семантике глаголов гулять, играть, веселить и однокоренных с ними единиц. Связанные с представлением о жизненной энергии и «разгуле», они называют процесс брожения спиртных напитков и их способность воздействовать на организм, ср.: арх. леш. весёлое 'спиртное' (АОС, вып. 3, с. 162), арх., волог., костром. навесели́ть 'положить закваску в пиво’ (КСГРС; СРНГ, вып. 19, с. 160), костром. играть 'бродить (о закваске)' (ЛКТЭ), костром. галич. разгу́льчивый 'веселящий (о хмельном напитке)': «Бражка пьяная - хмельная и разгульчивая» (СРНГ, 
вып. 33, с. 318); ср. также: сиб. забалу́й 'пиво, брага' (СРНГ, вып. 9, с. 244).

Некоторые наименования браги содержат антропоморфные образы, связанные с процессом брожения напитка. Например, мотив болтовни отразился в костром. барми́ха 'брага': «Бармуху выпьешь и бармишь - разговариваешь не знаю чего» (шар.), сопоставимом с костром. бармить 'быстро или непонятно говорить' (вохом., окт., шар.) (ЛКТЭ); общенародное наименование некачественного напитка бормоту́ха соотносится с гл. бормотать через цепочку семантических переходов 'что-л. неясно сказанное' > 'ерунда, вздор' > 'некачественный напиток'. «Говорящим» или «бормочущим» представляется спиртной напиток, в котором происходит брожение, сопровождаемое образованием пузырьков воздуха, ср.: новг. бормота́ть 'бродить (о пиве)': «А пиво-то хорошее у нас варят разваром, каменье таки горячи кладут, пока оно остепенится, не будет бормотатьто» (СРГК, т. 1, с. 97), среднеурал. говорунья 'брага' (ДЭИС), брюзжит, как худое пиво (Даль, т. 1, с. 133). Напротив, напиток, в котором приостановлена ферментация, определяется как «немой», ср.: немое вино 'окуренное серой, чтобы не бродило; им подправляют вина, чтобы не кисли' (Даль, т. 2, с. 562), а также неоднозначное в плане мотивационной интерпретации среднеурал. молча́нка 'вид браги': «Мы теперь брагу не ставим - молчанку. Стоит - молчит, пьем - молчим; Купи в магазине квасу да дрожжей - вот и молчанка будет» (ДЭИС). Возможно, ключ к пониманию названия кроется в контексте, указывающем на отсутствие бурного брожения, присущего браге и квасу. Кроме того, мотив болтовни отразил стереотипное представление о болтливости, вызываемой алкогольным опьянением, ср.: яросл. разгово́реи 'хмельной напиток' (ЯОС, т. 8, с. 115), тогда как молчанка, в отличие от браги, пьется в тишине.

Основная ценность самогона и браги для крестьянина состояла в хмельном эффекте, а их вкусовые качества, несомненно, ценились ниже, чем вкус пива. Крепость, резкость вкуса и воздействие напитков на организм человека находят воплощение в таких названиях крепкой браги или самогона, как арх. котл. головоло́мка 'крепкий спиртной напиток, бра- га' (СГРС, т. 3, с. 78), костром. пыщ. косорьі́ ловка 'самогон': «Мы звали ее косорыловка, самогонку-то. Очень крепкая, только выпьешь - перекосит» (ЛКТЭ), волог. баб., сок., у-куб. стенола́з 'крепкая брага': «Наварим бражки да не пьянеем, а молодяшка-то пьянеет от своего стенолаза» (у-куб.) (КСГРС); ср. также: волог. ник. разо́рва 'снадобья, которые приносят вред вместо пользы', 'какаялибо спиртосодержащая жидкость': «Всю разорву перепили» (КСГРС). Негативное вкусовое восприятия напитка, вероятно, передается в арх. вин. дику́ша 'брага': «Дикушу сварят, так весь поселок неделю гуляет» (СГРС, т. 3, c. 227), хотя народная версия происхождения названия связывает его с прил. дикий 'грубый, необузданный’, то есть характеризует воздействие на психику человека.

Способность алкоголя нарушать физическую координацию нашла отражение в таких словах, как арх. прим. завалихха 'крепкая брага': «Завалиха с ног валит» (СГРС, т. 4, с. 22), костром. кологр. коря́жничек 'простая сивушная водка' (СРНГ, вып. 42, с. 42) при арх. холм. коря́жить 'корчить, коробить, перегибать', пск., твер. коря́житься 'чувствовать приступы болезни' (СРНГ, вып. 15, с. 41). Вологодское и костромское название шату́н 'брага; крепкий самодельный спиртной напиток': «Стопочки две выпьешь этого шатуна и ошабуришься» (тот.); «Тятя мой такой шатун делал: незаметно с ног сбивал» (чухл.) (КСГРС; Ганцовская) - интересно тем, что позволяет выявить соотношение значений 'алкогольный напиток' - 'беспутный человек', характерное для номинаций хмельных напитков. Так, наряду с шатун 'брага' встречается арх. карг. шату́н 'беспутный человек' (СРГК, т. 6, с. 843), тул. шат 'ничем не занимающийся, лентяй' (Опыт, с. 263).

Лексемы со значениями 'брага' и 'пройдоха; лентяй' нередко входят в одно этимолого-словообразовательное гнездо, хотя они далеко не всегда мотивационно связаны друг с другом. В этом отношении интересно рассмотреть историю костромского бамальі́zа 'брага': «Нюхательный табак в башалыгу добавляли» (ЛКТЭ), которое было единожды записано в Вохомском районе в значении 'особо крепкий, «забористый» напиток'. Помимо наименования браги башальіга на этой же тер- 
ритории известно бамальі́га 'плеть, которой муж бил жену’: «Башалыга - это плеть, хлестать женщин. Муж сплетет из трех волос и бьет жену. Это только женщин хлестать» (ЛКТЭ). Происхождение костромского башальі́га 'плеть, кнут' можно связать с польск. диал. basałyga, basatyk 'кнут из лыка', 'бездельник, простак, деревенщина' (SGP, t. 1, s. 54), которое A.Е. Аникин считает одним из возможных этимонов для рус. басалай 'щеголь', ‘беспутный человек, хулиган', поскольку «образование пейор. назв. лиц типа басалыга от назв. кнута, бича не редкость» (Аникин, вып. 2, с. 243). На территории Русского Севера заимствования из польского языка не единичны и представляют собой системное явление (ср.: гл. трафить, коштовать, сущ. мазур и др. примеры в [Березович, 2017]). Как отмечает Е.Л. Березович, «западнославянские заимствования в русских говорах, далеких от зон непосредственного контакта с носителями соответствующих языков, отнюдь не являются редкостью. Это заимствования разного времени (от старых до новейших, связанных с трагическими военно-политическими событиями XX в.)» [Березович, 2017, с. 23].

Костромское слово башальі́га в значении 'плеть, кнут', которое ранее не фиксировалось лексикографическими источниками, можно рассматривать как веский аргумент в пользу происхождения русских диалектных форм башальі́zа / басалай из польского языка. Благодаря записанному башальіга 'плеть, кнут' стало очевидно, что первичное и вторичное значения в польском языке и в костромских говорах совпадают. Так, польск. basałyga называет кнут из лыка и простака, бездельника, а костром. башальга - плеть из волос, басалай, басальі́zа, бамала́ - беспутного человека, хулигана: в Октябрьском районе Костромской области известна форма бамала́ в выражении ди́кая бамала́ 'бран. о человеке': «Кто-нибудь с кем-нибудь разругается, дикая твоя башала, дикая твоя голова» (ЛКТЭ), в Ярославской области басальі́а 'шалун' (ЯОС, т. 1, с. 39), которое фонетически наиболее близко польскому этимону. Фонетическим и словообразовательным изменениям польск. basatyga (башальга > башала) в русских говорах способствовала экспрессивность его семантики. Костромское башальі́zа 'крепкая брага' могло появиться на русской почве как на основе значения 'кнут, плеть' (как то, что сшибает, ударяет), так и на основе значения башала́ (бамальі́za) 'хулиган, пройдоха'. Соотношение значений 'пройдоха, обманщик' и 'алкогольный напиток' в рамках одного этимолого-словообразовательного гнезда типично для наименований хмельных напитков, ср.: арх. свисту́н 'пиво третьего слива', пин. 'врун', свердл. 'болтун, обманщик' (СРНГ, вып. 36, с. 301), костром. прощельі́zа 'пиво второго или третьего слива', 'мот, ветреный человек', 'обманщик, лгун, хвастун' (СРНГ, вып. 33, с. 57), кадн. волог. едунда́ 'прозвище вздорного, задиристого крестьянина', симб. 'жидкий, безвкусный напиток (квас или бражка)' (СРНГ, вып. 9, с. 35). Учитывая спектр значений гнезда башалыга / басальгга и их экспрессивность, можно предположить, что слово было заимствовано в севернорусские говоры из речи ссыльных поляков (особенно примечательно значение 'плеть, кнут', которое связано с реалиями жизни ссыльных).

Как мы уже отметили, брага и самогон считались напитком второго сорта: их готовили из отходов, например из пивной гущи. В языке этот факт нашел отражение в мотивационной связи 'пивной осадок, гуща; остаток', 'бурда, мутное питье; некачественная жидкость' и 'брага; самогон', ср.: костром. пав., вохом. барда́ 'самогон, брага', 'забродившая смесь для самогона', 'осадок в пиве или квасе', арх. уст., волог. баб., устюж. ба́рда́ 'перекисшее пиво; брага', арх. вельск. 'мутная вода' (СГРС, т. 1, с. 63); волог. к-г, ник. бардома́ 'брага', 'пивная гуща', 'жидкое пиво или суп', 'мутная жидкость' (КСГРС); арх. уст., волог. ник. бурдома́zа 'брага', 'плохо приготовленная похлебка', волог. 'мутная грязная вода' (КСГРС). Формы барда́, бардома́ и бурдома́zа, вероятно, являются родственными или подвергались взаимной контаминации, восходят к рус. бурда́ 'дурной, мутный напиток', 'смесь, что-л. перемешанное', 'смесь кушаний' (Аникин, вып. 5, с. 155). Вологодское к-г. бахторма́ 'домашнее пиво, брага', 'плохо сваренный алкогольный напиток' стало результатом семантического развития арх. в-т., волог. к-г бахтарма́ 'осадок от пива, браги или другой процеженной жидкости’ 
(СГРС, т. 1, с. 79, 80). По предположению А.Е. Аникина, бахторма́ 'осадок от пива' может быть образовано от «бахтарма <'низ шляпки гриба, верх бересты’> как первоначальное назв. того, что не идет в пищу, выбрасывается (шершавая и/или “мохристая" пленка, кожица на шкуре, грибе, бересте - и осадок, остаток в пиве)» (Аникин, вып. 2, c. 296). Костромское вохом. бала́нда 'домашнее вино”: «Чача - это баланда, вино» (ЛКТЭ) - может быть словообразовательно связано с костром. вохом. бала́ндать 'делать что-то, связанное с водой': «Баландать - это значит кое-как постирать, пополоскать, побаландаться говорят» (ЛКТЭ), однако нельзя исключать и контаминацию с баланда́ диал. 'ботвинья', жарг. 'жидкая тюремная похлебка' (Аникин, вып. 2, с. 124).

Низкое качество браги опосредованно отражено в семантической модели 'отходы', 'что-л. ненужное' > 'брага'. Так, архангельское дура́нда 'недобродившее пиво, брага' (вельск.) (СРНГ, вып. 8, с. 262), по-видимому, производно от значения волог. бабуш., шексн., костром. шир. распр. дура́нда 'отходы от льняного семени, жмых' (СГРС, т. 3, с. 288). Название арх. лен., волог. тот., сямж. сулема́ 'некачественный алкогольный напиток', волог. чаг. шуле́мка 'домашний хмельной напиток': «Раньше было проще, всяку шулемку делали, и никто не штрафовал» (КСГРС) - восходит к широко распространенному на Русском Севере сулема́ 'всякий яд, отрава' (волог.), 'о чем-либо некачественном, неприятном' (волог.), 'чепуха, ерунда' (арх., волог.), 'некачественная пища' (волог. бел., кад.) (СРНГ, вып. 42, с. 219-220; КСГРС). В результате дальнейшего метонимического развития значения 'напиток' > 'емкость' появилось волог. хар. сул емá 'бутылка из-под спиртного напитка «Бальзам»”: «Раньше “Бальзам” вино было, красные бутылки, их сулема звали» (КСГРС). Возможно, что бутылочки с бальзамом напоминали емкости от сулемы-лекарства. Распространению слова сулема, известного как обозначение хлорида ртути, мог способствовать тот факт, что еще в XIX в. это ядовитое вещество использовалось врачами в качестве антисептического средства.

Архангельское буза́ 'хмельной настой из ягод’ (шенк.) (АОС, вып. 2, с. 167), единично записанное на северной территории, по мнению А.Е. Аникина, представляет собой заимствование, восходящее к кр.-тат., балк. $b u z a$, кбалк., кумык., ног. и др. boza 'хмельной напиток из перебродившего проса' (Аникин, вып. 5, с. 62). Известное южным говорам название буза 'алкогольный напиток' могло попасть на Русский Север с переселенцами из южных территорий. Этимологическая связь c арх. буза́ 'суматоха, беспорядок, ералаш' (лен.), 'ссора, скандал' (карг., кон., мез.) (АОС, вып. 2, с. 167) не является однозначной, поскольку последнее может быть родственно гл. бузить ‘бить, колотить' (Аникин, вып. 5, с. 70).

Интересный пример народной этимологии представляет слово ку́мушка 'брага, спиртной напиток домашнего приготовления’ (apx. лен., волог. баб., вашк., кад., костром. кадый., мак.) (ЛКТЭ; СГРС, т. 6, с. 272-273), которое явилось результатом народно-этимологического переосмысления формы кумьішка, ср.: волог. бел. кумьішка (СГРС, т. 6, с. 273) под влиянием термина родства кумушка, широко распространенного на Русском Севере в переносных значениях [см., например: (СГРС, т. 6, с. 271)]. Слово кумушка как обозначение домашнего спиртного напитка связывает говоры Русского Севера с говорами Центральной России, Поволжья и Урала, где записаны сходные формы, ср.: рус. морд., твер., яросл. пошех. ку́мушка 'брага, спиртной напиток домашнего приготовления' (СРНГ, вып. 16, с. 87; СРГМ), белгород., вят., оренб., прикам., ярослав. кумьішка (Моисеев, 2010, с. 78; ООСБ, c. 156; ОСВГ, вып. 5, с. 150-151; СГЮП, вып. 1, с. 444-445; ЯОС, т. 5, с. 107) и, вероятно, прикам. кубьішка 'вид самогона' (СГЮП, вып. 1, с. 444-445), фонетически измененное в народной речи.

Название спиртного напитка кумьі́шка (и ку́мушка) может восходить к тат. kumyz ‘перебродившее кобылье молоко': эпицентр распространения слова находится на территории Поволжья, где были не редки русско-тюркские контакты, ср.: у В.И. Даля: «Некоторые инородцы наши сидят или гонят вино из квашеного молока, это кумышка» (Даль, т. 1, с. 205). Судя по словообразовательной структуре слова, название кумылшка появилось в русских говорах как обозначение спиртного напитка из кумыса, который готовили многие 
тюркские народы, ср.: свердл. кумьі́ска 'самогон' (СРНГ, вып. 16, с. 88), в звуковом плане предшествующее форме кумьі шка. Эта версия поддерживается в этимологическом словаре Е.Н. Шиповой (Шипова, 1976) ${ }^{4}$. Несмотря на то, что в самих тюркских языках для обозначения самогона из кумыса употреблялось слово арак (арака), в русских говорах прижилось более привычное в звуковом плане слово кумышка с изначально прозрачной внутренней формой (кумылс-ка). Кроме того, слово кумышка оказалось созвучным термину крестного родства кумушка и включилось в языковую игру.

Проживающие на территории Поволжья финно-угорские народности - главным образом удмурты, а также марийцы и мордва, вероятно, могли заимствовать слово кумышка уже из русских говоров для обозначения самогона, который был их основным праздничным, обрядовым напитком. Особое распространение кумылшка получила у удмуртов, для которых «курение вина» было одним из традиционных занятий, а самогон - главным ритуальным напитком, ср.: удм. кумышка 'самогон' (УРС, с. 351). В.И. Даль определял кумышику именно как напиток удмуртов, чувашей и марийцев, ср.: «кумышка, ж., обл. мутная, дымная и вонючая перегонная брага (у вотяков, чуваш, черемис и др. чудских племен)» (Даль, т. 2, с. 218). Русское население считало кумышку напитком низких вкусовых качеств, поскольку она «сильно отзывается дымом и неприятным вкусом» (Моисеев, 2010, с.78).

Об употреблении кумышки «чудскими» народами было хорошо известно русскому населению, о чем свидетельствуют многочисленные контексты из русских диалектных словарей: «Вотяк приносит яйца и кумышку на могилу предка» (В.Г. Короленко. Мултанское жертвоприношение) (ССРЛЯ, т. 5, c. 1838); «Малмыжские марийцы без кумышки не живут»; «Из охмеляющих напитков вотяки употребляют только кумышку и пиво» (вят.) (ОСВГ, вып. 5, с. 150-151); «Каждая у черемис пирушка и жертвоприношение начинаются заблаговременно самими ими приготовленными крепко хмельными и для вкуса неприятными напитками, как-то: пивом, брагою, медом, кумышным вином» (оренб.)
(Моисеев, 2010, с. 78). В последнем контексте употребляется выражение кумьі шное вино, которое может быть как формой, искусственно созданной в письменном источнике, так и реальной диалектной лексемой, которая ценна тем, что подтверждает родство кумышка и кумыс (но не кума, кумуш$\kappa a)$, поскольку форма прилагательного кyмышное словообразовательно может восходить только к сущ. кумысс.

По данным Н.В. Пислегина, до конца XVIII в. существительное кумышка удмуртами не использовалось: «обычным наименованием кумышки среди северных удмуртов было вина, южных - арак» [Пислегин, 2016, с. 91]. Видится неслучайным, что время фиксации слова кумышка в удмуртском языке (не ранее конца XVIII в.) примерно совпадает со временем введения запретов на самогоноварение (о них см. подробнее: [Никитина, 2015; Пислегин, 2016]). Так, впервые системный государственный запрет оформили в середине XVIII в. законами 1749-1751 гг. в этот период у удмуртов, татар и бесермян проходили многочисленные проверки и массово изымали посуду для самогоноварения [Пислегин, 2016, с. 91]. Можно предположить, что именно в этот период слово кумылика было заимствовано из русских говоров в тюркские и некоторые финно-угорские языки, где и использовалось как эвфемизм вместо исконного (прежнего) наименования самогона: таким образом жители скрывали информацию о производстве алкоголя. Именно благодаря своей конспиративной функции слово кумышкка могло прижиться в удмуртском, татарском, башкирском, чувашском языках, став основным обозначением спиртного напитка домашнего приготовления и вытеснив некоторые исконные наименования, ср.: тат. көмешка (Ганиев, 2002, с. 200), башк. көмөикә (БРС, с. 279), чуваш. кумӑшка, кумӑшкӑ (Федотов, с. 306).

Эвфемизацию можно считать одной из главных особенностей названий крепких спиртных напитков, употребление которых не раз попадало под государственные запреты и вынуждало изготовителей и потребителей самогона скрываться от представителей власти. К группе эвфемизмов можно отнести, например, наименования, восходящие к цветообозначениям: «красные» наименования для 
вина - костром. пав. кра́сненькая (ЛКТЭ), волог. выт. румя́неи (СРНГ, вып. 5, с. 583), «синие» и «серые» для браги, самогона - арх. лен. си́вка, волог. в-уст. синее вино, «белые» для водки - волог. ник. бе́лая (КСГРС) ${ }^{5}$. В Октябрьском районе Костромской области для обозначения самогона использовались словосочетания с родовым словом водичка или масло, определение в которых намекало на технологию приготовления напитка: дыімная водичка (то есть приготовленная пугем «курения〉 на самогонном аппарате), ки́сленькая водичка (кисловатый привкус домашнего напитка), ржаное масло (приготовление на основе зерна) (ЛКТЭ).

Названия-эвфемизмы скрывали информацию не только от представителей государства, но и чужих людей и тех односельчан, кто не относился к участникам застолья. Они употреблялись в ситуации, когда питье алкоголя осуждалось членами семьи или социума. Например, название костром. го́лбешная (го́биешная), определяющее самогон через место его хранения (ср.: го́лбеи 'пристройка к печи, подполье'), было связано с ситуацией запрещенного питья алкоголя: «Нагонят самогонку да уберут в голбце, а он у матери украдет, придет да говорит, давай голбешную пить» (ЛКТЭ). Удобную систему шифрования качества самогона предлагают термины кровного родства - мужская пара отеи и сын, ср.: волог. оте́и 'крепкий, неразбавленный самогон': «Сам-то отец, а женишь - сын будет», тятька 'крепкий самогон': «Тятьки нахлебался, дак не ять» (устюж.), арх. па́сынок 'самогон второго разлива': «Первачка мне не дал почто, только пасынка» (КСГРС).

Для обозначения дистиллированных напитков типичны словосложения корня -сам- и глагольной основы (по типу самогон и самовар), ср.: кал-, калить - арх. котл. самока́л (КСГРС), кур-, курить - арх. вил. самоку́р (КСГРС), костром. окт. самоку́рка 'самогон' (ЛКТЭ), также: костром. окт., пав. кури́ть 'готовить, варить самогон' (ЛКТЭ), волог. кури́ть 'варить пиво с образованием пара' (СВГ, т. 4, с. 22). Аналогично от основ друг'другой, второй' и род-, родить образовано волог. баб. другоро́ 'самогон второго слива' (КСГРС). Широкая вариативность глагольных основ также могла определяться конспиративной функцией названий, которая раскрывается в одном из контекстов: «Самокал, чтобы маленькие дети не разглашали» (КСГРС).

Существование этой семантико-словообразовательной модели, вероятно, помогает объяснить происхождение арх. карг. сумато́$x a$ 'брага': «Он суматохи-то давно не гнал, с ума сводит, вот и суматоха» (СРНГ, вып. 36 , c. 107). С одной стороны, название может быть результатом семантической деривации cyмато́ха 'беспорядок, скандал' > 'хмельной напиток', примеры которой были рассмотрены выше. С другой - сопоставление с костром. ветл. самото́ха, самото́шка 'водка, самогон' (СРНГ, вып. 36, с. 107) позволяет предположить, что суматоха представляет собой народноэтимологический вариант слова самотоха, которое в свою очередь могло возникнуть из *амоток $(a)$, образованного аналогично приведенным выше самогон, $c a$ мокур, самокал на основе корней сам- и ток(течь). Существительное самоток в значении 'самогон' нам не встречалось, однако в русских говорах оно известно, например, в значении 'чистый, прозрачный мед, стекающий сам из выломаных сотов' (Даль, т. 2, с. 910) или в выражении Аннушка-пряльясамото́ка (смол.) (Добровольский, 1914, c. 11), указывающем на «автоматизированность» процесса прядения.

В качестве эвфемистических названий спиртных напитков в костромских говорах использовались формы из бытовавших здесь условных языков. К языку офеней восходят владимир., костром., твер., яросл. аланя и ела́ха 'пиво, бражка, брага' (СРНГ, вып. 1, c. 231 ; т. 8 , с. 338 ), этимоном которых может быть слав. ол 'всякий хмельной напиток' (см. подробнее: [Осипова, 2017]). Учитывая дату фиксации (1852 г.), происхождение из условно-профессиональных языков можно предположить для костром. торо́ 'водка' (СРНГ, вып. 44, с. 280). По предположению Г.Ю. Багриновского, этот диалектизм является синкопированным образованием от сущ. тарно 'водка' (торно, торло и др.), употреблявшимся в том числе в офенском языке. Вариант тарно́ мог возникнуть путем замены начального ви- на тор- / map- в сущ. вино (Багриновский, 2008, с. 523, 524): подобный способ формирования новых слов путем замены начального слога в общенародной форме типи- 
чен для условных языков. Форме торо, возможно, генетически родственно арх. уст. торока́ница 'брага': «Вина не продают, я и говорю этому тунеядцу: “Насоплись своей тороканицы!”» (КСГРС). Экспрессивность слова могла быть следствием его происхождения из условных языков, формы которых воспринимались как чуждые и непривычные. Тем не менее существует и более «прозаичный» вариант происхождения слова от таракан: жаргонное слово тарака́новка в значении 'жидкость для борьбы с тараканами' и далее - 'дешевый, некачественный спиртной напиток' (БСРЖ, с. 581).

В костромских говорах известно слово суле́u 'хмельные напитки, подаваемые на стол': «Это на столе сулеи, наподобие пива» (пав.) (ЛКТЭ). Исходя из особенностей семантики, оно мотивировано названием сосуда, в котором выносилось на стол. Однако возможно и формирование значения 'напиток' у приставочного деривата корня лить, без промежуточного звена 'бутылка'. Таким же путем были образованы костром. пав. суле́й, окт. суло́й 'пивное сусло', пав. суле́йка, сулея́'блины, оладьи': «Сулея - старое-старое слово, сейчас шаньги» (ЛКТЭ), то есть то, что сливается, наливается. Словообразовательная структура, архаичность приставки, устойчивые фольклорные формулы («На поли́це блины, на столе сулея») и замечание диалектоносителя об архаичности слова показывают, что суле́и для костромских говоров являлось исконным, не связанным с жаргонным сулей$\kappa a$. В то же время записанное в Октябрьском районе суле́йка 'бутылка' имеет жаргонное происхождение. По наблюдениям Г.Ю. Багриновского, общеарг. суле́йка 'водка' связано с распространенным в XIX в. сулейка 'бутылка' Переход 'бутылка водки' > 'водка' произошел в уголовном жаргоне (Багриновский, 2008, c. 519-520).

\section{Выводы}

Традиция питья браги и самогона в большей степени характеризует Костромскую, в меньшей - Архангельскую и Вологодскую области, где более устойчивой была традиция пивоварения. По мере продвижения к югу севернорусской зоны лексика пивоварения сменяется лексикой «бражничества», а затем - и самогоноварения.

Специфические семантико-мотивационные модели, характерные для названий браги и самогона, отразили технологию приготовления (самокур, другород), состав (приготовленные из пивных отходов барда, бахторма), цвет (красненькая, синее вино), низкое качество напитка (баланда, дуранда, сулема) воздействие на организм человека (головоломка, косорыловка, завалиха, шатун). Потребность скрывать приготовление и употребление самогона от власти определялась государственными запретами на производство алкоголя. Кроме того, оно скрывалось от посторонних и детей, которые случайно могли выдать самогонщиков. С этим связано большое количество эвфемизмов (кисленькая водичка, ржаное масло, голбешная и др.), а также вариативность, многочисленность наименований и большое количество фактов единичной фиксации (буза, суматоха, тороканица и др.). В названиях самогона представлены заимствования из волжских говоров (буза, кумушка), условно-профессиональных языков (аланя, елаха, торо). Поскольку брага и другой алкоголь чаще всего употребляются в ситуациях застолья и веселья, связанных как с непринужденной беседой, так и словесной перепалкой, многие лексемы получают шутливые коннотации и становятся частью языковой игры, ср: стенолаз, коряжничек, румянец, кумушка, суматоха.

\section{ПРИМЕЧАНИЯ}

${ }^{1}$ Исследование выполнено при поддержке гранта РНФ № 20-18-00223 «Этимологизация и семантическая реконструкция русской диалектной лексики».

The research is carried out within the project 20-18-00223 "Etymological and Semantic Reconstruction of the Russian Dialect Vocabulary" supported by the Russian Science Foundation.

${ }^{2}$ В то же время ср.: Христос прокатился по груди 'слова, которые говорят, выпив спиртное' (КСГРС).

${ }^{3}$ А.Е. Анинин толкует сущ. брага как заимствование: «в др.-рус. *бърага (до падения редуцированных) из др.-чув. *bura $+-k a$, ср.: чув. pəra-Ga ‘выжимки' (<? ‘жидкое пиво, брага')» (Аникин, вып. 4, с. 140). 
${ }^{4}$ В статье Н.В. Пислегина высказываются сомнения в правомерности сопоставления сущ. кумылшка и кумыс и приводится высказанное В.С. Чураковым предположение о происхождении удм. кумьікка «от русского слова “кумушка” (изначально удм. кума вина лучший сорт кумышки), то есть она была напитком, приготовляемым для потчевания “воспреемников” при крещении, первоначально, как правило, русских» [Пислегин, 2016, с. 91]. Предлагаемая версия кажется нам маловероятной, поскольку «крестильная» функция кумушки была не основной.

${ }^{5}$ Подробно цветовая символика в наименованиях спиртных напитков раскрывается в (Багриновский, 2008).

\section{СПИСОК ЛИТЕРАТУРЫ}

Березович Е. Л., 2014. Русская лексика на общеславянском фоне: семантико-мотивационная реконструкция. М. : Рус. фонд содействия образованию и науке. 488 с.

Березович Е. Л., 2017. К изучению западнославянских заимствований в русских народных говорах // Etymological Research of Czech. Proceedings of the Etymological Symposium (Brno 2017, 12-14 September, 2017). Praha : Nakladatelství Lidové noviny. S. 11-25. (Studia etymologica Brunensia 22).

Леонтьева Т. В., 2015. Модели и сферы репрезентации социально-регулятивной семантики в русской языковой традиции : дис. ... д-ра филол. наук. Екатеринбург. 427 с.

Никитина Г. А., 2015. Кумышка в традиционном обществе и в современной жизни удмуртов // Здоровье, демография, экология финноугорских народов. № 1. С. 33-36.

Осипова К. В., 2017. Лексика пивоварения на Русском Севере: этнолингвистический аспект // Вестник Томского государственного университета. Филология. № 48. С. 57-73. DOI: $10.17223 / 19986645 / 48 / 4$.

Осипова К. В., 2018. Названия спиртных напитков на Русском Севере: этимолого-этнолингвистический анализ // Вестник Томского государственного университета. Филология. № 56. C. 146-165. DOI: 10.17223/19986645/56/8.

Пислегин Н. В., 2016. Удмуртская кумышка: документальные свидетельства повседневности второй половины XVIII-XIX вв. // Вестник Калмыцкого института гуманитарных исследований РАН. Т. 27, № 5. C. 90-96. DOI: 10.22162/2075-7794-2016-27-5-90-964.

Толстой Н. И., 2013. Язык и культура // Толстой Н. И., Толстая С. М. Славянская этнолингвистика: вопросы теории. М. : Ин-т славяноведения РАН. С. 7-18. (Материалы ко Второму Всероссийскому совещанию славистов, 5-6 ноября 2013 г.)

\section{ИСТОЧНИКИ И СЛОВАРИ}

Аникин-Аникин А. Е. Русский этимологический словарь. Вып. 1- . М. ; СПб. : [б. и.] , 2007- .

$A O C$ - Архангельский областной словарь / под ред. О. Г. Гецовой. Вып. 1- . М. : Изд-во МГУ, $1980-$

Багриновский, 2008 - Багриновский Г. Ю. Энциклопедический словарь спиртных напитков : Свыше 3500 названий : История спиртных напитков от глубокой древности до наших дней. М. : Астрель : АСТ, 2008. 1342 с.

БРС - Башкирско-русский словарь. М. : Гос. изд-во иностр. и нац. слов., 1958. 804 с.

БСРЖ - Мокиенко В. М. Большой словарь русского жаргона : 25000 слов, 7000 устойчивых сочетаний / В. М. Мокиенко, Т. Г. Никитина. СПб. : Норинт, 2000. 716 с.

Ганиев, 2002 - Татарско-русский словарь : 25000 слов / И. А. Абдуллин [и др.] ; под ред. Ф. А. Ганиева. Казань : Тат. кн. изд-во, 2002. 488 с.

Ганцовская - Ганцовская Н. С. Словарь говоров Костромского Заволжья: междуречье Костромы и Унжи (с эпицентром акающих говоров). (Рукопись).

Даль - Даль В. И. Толковый словарь живого великорусского языка : в 4 т. М. : Гос. изд-во иностр. и нац. слов., 1955. 4 т.

Добровольский, 1914 - Смоленский областной словарь / сост. В. Н. Добровольский. Смоленскъ : Типографія П. А. Силина, 1914. 1022 с.

ДЭИС - Традиционная культура Урала : Диалектный этноидеографический словарь русских говоров Среднего Урала / авт.-сост.: О. В. Востриков, В. В. Липина. Екатеринбург : [б. и.], 2009. 1 электрон. опт. диск (CD-ROM).

Ефименко - Ефименко П. С. Материалы по этнографии русского населения Архангельской губернии. В 2 ч. Ч. 2. Народная словесность. М. : Типо-лит. С. П. Архипова и К, $1878.276 \mathrm{c}$.

КСГРС - Картотека Словаря говоров Русского Севера. (Хранится на кафедре русского языка, общего языкознания и речевой коммуникации УрФУ, г. Екатеринбург).

ЛКТЭ - Лексическая картотека Топонимической экспедиции Уральского университета. (Хранится на кафедре русского языка, общего языкознания и речевой коммуникации УрФУ, г. Екатеринбург). 
Моисеев, 2010 - Моисеев Б. А. Оренбургский областной словарь : 5698 слов и словосочетаний / Б. А. Моисеев. Оренбург : Изд-во ОГПУ, 2010. $192 \mathrm{c}$.

ООСБ - Кошарная С. А. Опыт областного словаря Белгородчины: дифференц.-сопостав. слов. / С. А. Кошарная, А. С. Алейник, А. И. Медведева. Белгород : Эпицентр, 2017. 330 с.

Onblm - Опыт областного великорусского словаря, изданный Вторым отделением Академии наук / ред. А. Х. Востоков. СПб. : Тип. Император. акад. наук, 1852. 275 с.

ОСВГ-Областной словарь вятских говоров / под ред. В. Г. Долгушева, 3. В. Сметаниной. Вып. 1- . Киров : Коннектика : Изд-во ВятГГУ : РадугаПРЕСС, 1996- .

СВГ-Словарь вологодских говоров : в 12 т. / под ред. Т. Г. Паникаровской. Вологда : Изд-во ВГПИ / ВГПУ, 1983-2007. 12 т.

СГРС - Словарь говоров Русского Севера / под ред. А. К. Матвеева. Т. 1- . Екатеринбург : Изд-во Урал. ун-та, 2001-

СГЮП-Подюков И. А. Словарь русских говоров Южного Прикамья. Вып. 1-3. Пермь : Изд-во ПГГПУ, 2010-2012.

СРГК - Словарь русских говоров Карелии и сопредельных областей : в 6 т. / гл. ред. А. С. Герд. СПб. : Изд-во СПбГУ, 1994-2005. 6 т.

СРГМ - Словарь русских говоров на территории Республики Мордовия : в 2 ч. / отв. ред. Р. В. Семенкова. СПб. : Наука, 2013. 1560 с. 2 ч.

СРНГ - Словарь русских народных говоров / гл. ред. Ф. П. Филин, Ф. П. Сороколетов, С. А. Мызников. Вып. 1- . М. ; Л. ; СПб. : Наука, 1965- .

ССРЛЯ - Словарь современного русского литературного языка : в 17 т. / В. И. Чернышев (гл. ред.) [и др.]. М. ; Л. : Изд. и 1-я тип. изд-ва Акад. наук СССР в Л., 1948-1965. 17 т.

Тенишев - Русские крестьяне. Жизнь. Быт. Нравы : материалы «Этнографического бюро» князя В.Н. Тенишева. Т. 5. Вологодская губерния. Ч. 3. Никольский и Сольвычегодский уезды. СПб. : Деловая полиграфия, 2007. 683 с.

УРС - Удмуртско-русский словарь : Около 50000 слов / сост.: Т. Р. Душенкова [и др.] ; отв. ред. Л. Е. Кириллова. Ижевск : [б. и.], 2008. 925 с.

Федотов - Федотов М. Р. Этимологический словарь чувашского языка. В 2 т. Т. 1. Чебоксары : Чуваш. гос. ин-т гуманитар. наук, 1996. $981 \mathrm{c}$.

Шипова - Шипова Е. Н. Словарь тюркизмов в русском языке / отв. ред. А. Н. Кононов. АлмаАта : «Наука» КазССР, 1976. 392 с.

ЯОС - Ярославский областной словарь : в 10 т. / отв. ред. Г. Г. Мельниченко. Ярославль : ЯГПИ им. К.Д. Ушинского, 1981-1991. 10 т.
$S G P$ - Karłowicz J. Słownik gwar polskich. T. 1-6, Kraków : Nakładem Akademii Umiejętności, Drukarnia C.K. Uniwersytetu Jagiellońskiego, 1900-1911.

\section{REFERENCES}

Berezovich E.L., 2014. Russkaya leksika na obshcheslavyanskom fone: semantikomotivatsionnaya rekonstruktsiya [Russian Vocabulary on the Pan-Slavic Background: Semantic and Motivational Reconstruction]. Moscow, Russkiy fond sodeystviya obrazovaniyu i nauke. 488 p.

Berezovich E.L., 2017. K izucheniyu zapadnoslavyanskikh zaimstvovaniy v russkikh narodnykh govorakh [To the Study of West Slavic Borrowings in Russian Folk Dialects]. Etymological Research of Czech. Proceedings of the Etymological Symposium (Brno 2017, 12-14 September 2017). Prague, Nakladatelství Lidové noviny, pp. 11-25. (Studia etymologica Brunensia 22).

Leontyeva T.V., 2015. Modeli i sfery reprezentatsii sotsialno-regulyativnoy semantiki v russkoy yazykovoy traditsii: dis. ... d-ra filol. nauk [Models and Fields of Representation of SocioRegulatory Semantics in the Russian Language Tradition. Dr. philol. sci. diss.]. Yekaterinburg. $427 \mathrm{p}$.

Nikitina G.A., 2015. Kumyshka v traditsionnom obshchestve i v sovremennoy zhizni udmurtov [Home-Distilled Vodka in Traditional Society and Contemporary Life of the Udmurts]. Zdorovye, demografiya, ekologiya finno-ugorskikh narodov [Health, Demography, Ecology of Finno-Ugric People], no. 1, pp. 33-36.

Osipova K.V., 2017. Leksika pivovareniya na Russkom Severe: etnolingvisticheskiy aspekt [Brewing Vocabulary in the Russian North: An Ethnolinguistic Aspect]. Vestnik Tomskogo gosudarstvennogo universiteta. Filologiya [Tomsk State University Journal of Philology], no. 48, pp. 57-73. DOI: 10.17223/19986645/48/4.

Osipova K.V., 2018. Nazvaniya spirtnykh napitkov na Russkom Severe: etimologo-etnolingvisticheskiy analiz [Names of Strong Alcoholic Drinks in the Russian North: Etymological and Ethnolinguistic Analysis]. Vestnik Tomskogo gosudarstvennogo universiteta. Filologiya [Tomsk State University Journal of Philology], no. 56, pp. 146-165. DOI: $10.17223 / 19986645 / 56 / 8$.

Pislegin N.V., 2016. Udmurtskaya kumyshka: dokumentalnye svidetelstva povsednevnosti vtoroy poloviny XVIII-XIX vv. [The Udmurt 
Kumyshka: Documentary Evidence of Everyday Life in the Latter Half of the $18^{\text {th }}-19^{\text {th }}$ cc.]. Vestnik Kalmytskogo instituta gumanitarnykh issledovaniy RAN [Bulletin of the Kalmyk Institute for Humanities of the Russian Academy of Sciences], vol. 27, iss. 5, pp. 90-96. DOI: 10.22162/2075-7794-2016-27-5-90-964.

Tolstoy N.I., 2013. Yazyk i kultura [Language and Culture]. Tolstoy N.I., Tolstaya S.M. Slavyanskaya etnolingvistika: voprosy teorii [Slavic Ethnolinguistics: Theory Questions]. Moscow, Institut slavyanovedeniya RAN, pp. 718. (Materialy ko Vtoromu Vserossiyskomu soveshchaniyu slavistov 5-6 noyabrya $2013 \mathrm{~g}$. [Materials for the Second All-Russian Meeting of Slavists, November 5-6, 2013]).

\section{SOURCES AND DICTIONARIES}

Anikin A.E. Russkiy etimologicheskiy slovar [Russian Etymological Dictionary]. Iss. 1-12. Moscow, Saint Petersburg, [s. n.], 2007-2018.

Getsova O.G., ed. Arkhangelskiy oblastnoy slovar [Arkhangelsk Regional Dictionary]. Iss. 1- . Moscow, Izd-vo MGU, 1980- .

Bagrinovskiy G.Yu. Entsiklopedicheskiy slovar spirtnykh napitkov: Svyshe 3500 nazvaniy: Istoriya spirtnykh napitkov ot glubokoy drevnosti do nashikh dney [Encyclopedic Dictionary of Alcoholic Beverages: Over 3500 Titles: History of Alcoholic Beverages from Ancient Times to the Present Day]. Moscow, Astrel Publ., AST Publ., 2008. 1342 p.

Bashkirsko-russkiy slovar [Bashkir-Russian Dictionary]. Moscow, Gosudarstvennoe izd-vo inostrannykh i natsionalnykh slovarey, 1958. $804 \mathrm{p}$.

Mokienko V. M., Nikitina T. G. Bolshoy slovar russkogo zhargona: 25000 slov, 7000 ustoychivykh sochetaniy [Large Dictionary of Russian Jargon: 25000 Words, 7000 Stable Combinations]. Saint Petersburg, Norint Print, 2000. 716 p.

Abdullin I.A., Ganiev F.A., Mukhamadiev M.G., Yunaleeva R.A. Tatarsko-russkiy slovar: 25000 slov [Tatar-Russian Dictionary: 25,000 Words]. Kazan, Tatarskoe knizhnoe izdatelstvo, 2002. $488 \mathrm{p}$.

Gantsovskaya N.S. Slovar govorov Kostromskogo Zavolzhyya: mezhdurechye Kostromy i Unzhi (s epitsentrom akayushchikh govorov) [Dictionary of Dialects of the Kostroma Transvolga Region: Interfluve of Kostroma and Unzha (With the Epicenter of the Dialects with the Pronunciation of Russian Unstressed "o" as "a")]. (Manuscript).
Dal V.I. Tolkovyy slovar zhivogo velikorusskogo yazyka: $v 4 t$. [Explanatory Dictionary of the Living Great Russian Language. In 4 Vols.]. Moscow, Gosudarstvennoe izd-vo inostrannykh i natsionalnykh slovarey, 1955.4 vols.

Dobrovolskiy V.N. Smolenskiy oblastnoy slovar [Smolensk Regional Dictionary]. Smolensk, Tipografiya P.A. Silina, 1914. 1022 p.

Vostrikov O.V., Lipina V.V. Traditsionnaya kultura Urala: Dialektnyy etnoideograficheskiy slovar russkikh govorov Srednego Urala [Traditional Culture of the Urals: Dialectal Ethnoideographic Dictionary of Russian Dialects of the Middle Urals]. Yekaterinburg, 2009. 1 electronic optical disk (CD-ROM).

Efimenko P.S. Materialy po etnografii russkogo naseleniya Arkhangelskoy gubernii. Ch. 2. Narodnaya slovesnost [Materials on the Ethnography of the Russian Population of the Arkhangelsk Province. Part 2. Folk Literature]. Moscow, Tipo-litografiya S.P. Arkhipova i $\mathrm{K}^{\circ}$, $1878.276 \mathrm{p}$.

Kartoteka Slovarya govorov Russkogo Severa [Card Index of the Dictionary of Dialects of the Russian North]. (Stored at the Department of the Russian Language, General Linguistics and Speech Communication, USU, Yekaterinburg).

Leksicheskaya kartoteka Toponimicheskoy ekspeditsii Uralskogo universiteta [Lexical Card Index of the Ural University Toponymic Expedition]. (Stored at the Department of the Russian Language, General Linguistics and Speech Communication, USU, Yekaterinburg).

Moiseev B.A. Orenburgskiy oblastnoy slovar. 5698 slov $i$ slovosochetaniy [Orenburg Regional Dictionary. 5698 Words and Phrases]. Orenburg, Izd-vo OGPU, 2010.192 p.

Kosharnaya S.A., Aleynik A.S., Medvedeva A.I. Opyt oblastnogo slovarya Belgorodchiny: differentsialno-sopostavitelnyy slovar [Experience of the Regional Dictionary of Belgorod Region: Differential-Comparative Dictionary]. Belgorod, Epitsentr Publ., 2017. 330 p.

Vostokov A.Kh., ed. Opyt oblastnogo velikorusskogo slovarya, izdannyy Vtorym otdeleniem Akademii nauk [Experience of the Regional Great Russian Dictionary Published by the Second Branch of the Academy of Sciences]. Saint Petersburg, Tipografiya Imperatorskoy akademii nauk, 1852. $275 \mathrm{p}$.

Dolgushev V.G., Smetanina Z.V., eds. Oblastnoy slovar vyatskikh govorov [Regional Dictionary of Vyatka Dialects]. Iss. 1- . Kirov, Konnektika Publ., Izd-vo VyatGGU, Raduga-PRESS, 1996- .

Panikarovskaya T.G., ed. Slovar vologodskikh govorov: v $12 \mathrm{t}$. [Dictionary of Vologda 
Dialects. In 12 Vols.]. Vologda, Izd-vo VGPI / VGPU, 1983-2007.

Matveev A.K., ed. Slovar govorov Russkogo Severa [Dictionary of Dialects of the Russian North]. Vol. 1- . Yekaterinburg, Izd-vo Uralskogo universiteta, 2001-

Podyukov I.A. Slovar russkikh govorov Yuzhnogo Prikamya. Vyp. 1-3 [Dictionary of Russian Dialects of the Southern Kama Region. Iss. 1-3]. Perm, Izd-vo PGGPU, 2010-2012.

Gerd A.S., ed. Slovar russkikh govorov Karelii $i$ sopredelnykh oblastey: $v 6 t$. [Dictionary of Russian Dialects of Karelia and Adjacent Regions. In 6 Vols.]. Saint Petersburg, Izd-vo SPbGU, 1994-2005.

Semenkova R.V., ed. Slovar russkikh govorov na territorii Respubliki Mordoviya. V 2 ch. [Dictionary of Russian Dialects on the Territory of the Republic of Mordovia. In 2 ch.]. Saint Petersburg, Nauka Publ., 2013. 1560 p.

Filin F.P., Sorokoletov F.P., Myznikov S.A. Slovar russkikh narodnykh govorov [Dictionary of Russian Folk Dialects]. Iss. 1- . Moscow, Leningrad, Saint Petersburg, Nauka Publ., 1965- .

Chernyshev V.I. et al., eds. Slovar sovremennogo russkogo literaturnogo yazyka: v $17 t$. [Dictionary of the Modern Russian Literary Language. In 17 Vols.]. Moscow, Leningrad, Izdvo i 1-ya tipografiya izd-va Akademii nauk SSSR v Leningrade, 1948-1965.
Russkie krestyane. Zhizn. Byt. Nravy: Materialy "Etnograficheskogo byuro» knyazya V.N. Tenisheva. T. 5. Vologodskaya guberniya. Ch. 3. Nikolskiy i Solvychegodskiy uezdy [Russian Peasants. Life. Everyday Life. Morals. Materials of the "Ethnographic Bureau" of Prince V.N. Tenishev. Vol. 5. Vologda Province. Part 3. Nikolsky and Solvychegodsky Uezds]. Saint Petersburg, Delovaya poligrafiya Publ., 2007. 683 p.

Dushenkova T.R., Egorov A.V., Ivshin L.M., Karpova L.L., Kirillova L.E., Titova O.V., Shibanov A.A., eds. Udmurtsko-russkiy slovar: Okolo 50000 slov [Udmurt-Russian Dictionary: About 50,000 Words]. Izhevsk, [s. n.], 2008. 925 p.

Fedotov M.R. Etimologicheskiy slovar chuvashskogo yazyka. V2 t. T. 1 [Etymological Dictionary of the Chuvash Language. In 2 Vols. Vol. 1]. Cheboksary, Chuvashskiy gosudarstvennyy institut gumanitarnykh nauk, $1996.981 \mathrm{p}$.

Shipova E.N. Slovar tyurkizmov v russkom yazyke [Dictionary of Turkisms in Russian]. Alma-Ata, «Nauka» KazSSR, 1976. 392 p.

Melnichenko G.G., ed. Yaroslavskiy oblastnoy slovar: v $10 t$. [Yaroslavl Regional Dictionary. In 10 Vols.]. Yaroslavl, YaGPI im. K.D. Ushinskogo, 19811991.

Karłowicz J. Słownik gwar polskich. T. 1-6. Kraków, Nakładem Akademii Umiejętności, Drukarnia C.K. Uniwersytetu Jagiellońskiego, 1900-1911.

\section{Information About the Author}

Ksenia V. Osipova, Candidate of Sciences (Philology), Senior Researcher, Toponymic Laboratory, Ural Federal University named after the first President of Russia B.N. Yeltsin, Prosp. Lenina, 51, 620000 Yekaterinburg, Russia, osipova.ks.v.@yandex.ru, https://orcid.org/0000-0002-2285-6112

\section{Информация об авторе}

Ксения Викторовна Осипова, кандидат филологических наук, старший научный сотрудник топонимической лаборатории, Уральский федеральный университет им. первого Президента России Б.Н. Ельцина, просп. Ленина, 51, 620000 г. Екатеринбург, Россия, osipova.ks.v.@yandex.ru, https://orcid.org/0000-0002-2285-6112 